\title{
Łukasz Grabowski
}

Instytut Językoznawstwa

Uniwersytet Opolski

lukasz@uni.opole.pl

\section{TEKSTY FARMACEUTYCZNE I DYSKURS FARMACEUTYCZNY: DEFINICJE, SPECYFIKA I KRÓTKI PRZEGLĄD POLA BADAWCZEGO}

\section{Wprowadzenie}

Większość współczesnych badań na styku farmacji, farmakologii i językoznawstwa, w tym zwłaszcza dotyczących zróżnicowania języka i rejestrów komunikacyjnych, prowadzonych jest nad tekstami, które można zaklasyfikować jako medyczne czy też biomedyczne. Język używany podczas opracowywania, badania lub dystrybucji leków, czy też szerzej, w różnych specjalistycznych kontekstach farmaceutycznych, bywa również klasyfikowany jako język medyczny (English for Medical Purposes ${ }^{1}$ ), język biomedycyny (Biomedical English ${ }^{2}$ ), język do celów zawodowych (English for Professional Purposes, English for Occupational Purposes) lub jeszcze bardziej ogólnie - jako język specjalistyczny (English for Specific Purposes). Także w Polsce dyskurs farmaceutyczny często traktowany jest jako składnik dyskursu medycznego (np. Ławnicka-Borońska 2013; Ławnicka-Borońska, Kubacka 2016).

Termin „dyskurs farmaceutyczny” jest rzadko używany w literaturze specjalistycznej. Niemniej specyfikę języka używanego w różnych kontekstach farmaceutycznych uwzględnia się chociażby $\mathrm{w}$ wypadku opracowywania

${ }^{1} \mathrm{~W}$ krajach anglojęzycznych również trudno odnaleźć podręczniki opracowane specjalnie dla języka angielskiego używanego w kontekstach farmaceutycznych (English for Pharmaceutical Purposes). Większość podręczników traktuje o języku medycznym, tj. English for Medical Purposes (EMP), np. Glendinning i Holmstroem (2005), Hull (2010), Allum (2012).

2 Takim określeniem posługują się np. Verdaguer i in. (2013). 
podręczników do nauki specjalistycznego języka angielskiego, przeznaczonych dla przyszłych farmaceutów pracujących nie tylko w aptekach, ale też w instytucjach i przedsiębiorstwach z branży farmaceutycznej. Dotychczas na samym tylko rynku polskim ukazało się kilka takich pozycji wydawniczych, np. English for Pharmacy: język angielski: podręcznik dla studentów farmacji (Ciecierska i in. 1983), English for Students of Pharmacy and Pharmacists (Donesch-Jeżo 2007), English for Pharmacists (Kierczak 2009), English for Pharmacists. Podręcznik (Dycha 2016), a także polskich wydań podręczników wydanych wcześniej na innych rynkach, np. Język angielski $w$ aptece (Carra, Hein 2007) i bazująca na nim późniejsza pozycja Język angielski $w$ aptece. Skills Upgrade (Lipińska, Wiśniewska-Leśków 2018).

$\mathrm{W}$ związku z tym, że o lekach mówimy w różnych sytuacjach codziennych i zawodowych (np. rozmowa pacjenta i farmaceuty w aptece, codzienna praca farmaceuty, komunikacja w aptece szpitalnej lub laboratorium farmaceutycznym, lektura ulotki dla pacjentów, lektura tekstów akademickich/specjalistycznych, prezentacja leku, rozmowy handlowe itp.), to i język (angielski, polski itp.) używany w każdej z nich będzie wykazywał wysoki stopień zróżnicowania na poziomie leksyki i frazeologii, gramatyki czy też pragmatyki. Wybór środków językowych zależy od uczestników i specyfiki sytuacji komunikacyjnej, o czym możemy się przekonać przyglądając się bliżej różnym typom i gatunkom tekstów farmaceutycznych, np. ulotkom dla pacjentów, charakterystykom produktów leczniczych, protokołom badań klinicznych, ulotkom reklamowym itp. $\mathrm{W}$ niniejszym artykule w dużym skrócie i uproszczeniu przybliżam specyfikę dyskursu farmaceutycznego i konstytuujących go tekstów farmaceutycznych, a także dokonuję przeglądu wybranych, najnowszych badań językoznawczych i interdyscyplinarnych nad tym dyskursem ${ }^{3}$.

\section{Dyskurs farmaceutyczny jako przykład dyskursu profesjonalnego}

Termin „dyskurs” można rozumieć w różny sposób. Van Dijk (2001: 10) wyróżnia trzy orientacje badawcze: 1) dyskurs jako użycie języka (wypowiedź lub tekst osadzony w określonym kontekście);2) dyskurs jako sposób przekazywania określonych idei; 3 ) dyskurs jako proces interakcji społecznej osadzony

${ }^{3}$ Artykuł ten w dużej mierze oparty jest na rozdziale pierwszym mojej monografii Phraseology in English Pharmaceutical Discourse: A Corpus-Driven Study of Register Variation (Grabowski 2015b), wydanej przez Wydawnictwo Uniwersytetu Opolskiego, które wyraziło pisemną zgodę na wykorzystanie fragmentów ww. rozdziału w niniejszej pracy. Rzeczoną zgodę przekazałem Redaktorom tomu. 
w warstwie społecznej, kulturowej, politycznej i ideologicznej ${ }^{4}$. Zdaniem Piekota (2014: 16) „dyskurs” można także rozumieć jako pojęcie abstrakcyjne (zbiór lub system norm, zasad, wzorców zachowań, który determinuje komunikację i powstawanie tekstów) lub jako konkretny byt (tekst lub podobny pod względem m.in. nadawcy, odbiorcy, funkcji, tematyki zbiór tekstów osadzony w określonym kontekście). Dyskurs farmaceutyczny, na który można spojrzeć z każdej z wyżej wymienionych perspektyw, to jeden z wielu typów dyskursu profesjonalnego. $\mathrm{Z}$ jednej strony stanowi profesjonalną odmianę języka, profesjolekt (gwarę zawodową) o ograniczonym zasięgu, którym posługują się poszczególne grupy zawodowe (farmaceuci, przedstawiciele farmaceutyczni, farmakolodzy itp.) połączone specyficznym rodzajem więzi społecznej, jaką jest praca w szeroko rozumianej branży farmaceutycznej. Z drugiej strony ów dyskurs nie istnieje w izolacji od innych dyskursów (medycznego, biomedycznego, prawniczego itp.), ponieważ funkcjonowanie w branży farmaceutycznej (w obszarze jej dyskursu) zależy od różnorakich uwarunkowań, chociażby prawno-instytucjonalnych czy etycznych. Należy więc zgodzić się ze stwierdzeniem badaczy, którzy nie traktują dyskursu farmaceutycznego jako autonomicznej odmiany dyskursu profesjonalnego, ale uznają go za złożony system międzydyscyplinarnej komunikacji (Dobronravov i in./Аобронравов и ар. 2017). W dyskursie farmaceutycznym przenikają się ze sobą dyskursy prawniczy, medyczny, akademicki, reklamowy, ekonomiczny i wiele innych (Kositskaja/Косицкая 2016: 72), ponieważ o lekach rozmawiają zarówno specjaliści, jak i niespecjaliści w zupełnie różnych sytuacjach komunikacyjnych i uwarunkowaniach instytucjonalnych. Przykłady użycia dyskursu farmaceutycznego obejmują np. rozmowę farmaceuty $\mathrm{z}$ pacjentem $\mathrm{w}$ aptece, codzienną pracę farmaceuty, konferencje specjalistyczne i szkolenia, korespondencję $\mathrm{z}$ organizacjami branżowymi, rozmowy handlowe, porozumiewanie się z personelem aptek ogólnodostępnych, aptek szpitalnych, laboratoriów farmaceutycznych, instytutów badawczych itp. Również lektura tekstów farmaceutycznych (np. ulotki informacyjnej dla pacjentów, charakterystyki produktu leczniczego) to przykład bezpośredniego kontaktu ze zinstytucjonalizowanym i skonwencjonalizowanym dyskursem farmaceutycznym. Można zatem powiedzieć, że dyskurs farmaceutyczny obejmuje całokształt użycia języka w szeroko rozumianej branży farmaceutycznej, sektorze ochrony zdrowia i sektorze nauki, gdzie stykamy się w taki czy inny sposób z lekami (produktami leczniczymi)

${ }^{4}$ Więcej o złożoności pojęcia „dyskurs” w perspektywie akademickiej piszą m.in. Kabus (2011), Dawidziuk (2014), Piekot (2014).

${ }^{5}$ Produkty lecznicze (leki) należy odróżnić od wyrobów medycznych, czyli w zasadzie wszystkich produktów przeznaczenia medycznego, które nie są lekami, np. strzykawka, igła, proteza (Mądry 2019). 
Uwzględniając złożoność i specyfikę dyskursu farmaceutycznego jako odmiany dyskursu profesjonalnego, dokładniej go teraz scharakteryzuję. Wykorzystam do tego celu niektóre elementy modeli opisowych zaproponowanych przez Bhatię (2004) i Gunnarson (2009).

Bhatia (2004: 114) wyszczególnia trzy elementy wiedzy specjalistycznej, a mianowicie wiedzę dyscyplinarną (dziedzinową), praktykę zawodową i kompetencje dyskursywne. W niniejszym artykule przeglądowym ten ostatni element ma kluczowe znaczenie, ponieważ dotyczy bezpośrednio kompetencji tekstowych. W praktyce kompetencje dyskursywne odnoszą się do umiejętności członków społeczności danego dyskursu (np. urzędników państwowych, lekarzy, farmaceutów, pielęgniarek, tłumaczy, pacjentów) związanych $\mathrm{z}$ korzystaniem $\mathrm{z}$ tekstów farmaceutycznych, tj. ich właściwego konstruowania i/lub interpretowania. Z tej perspektywy dyskurs farmaceutyczny, podobnie jak każdy dyskurs profesjonalny, może być również postrzegany jako zbiór znaczeń i wartości związanych z konkretnymi społecznościami i instytucjami branżowymi niejako zakodowany $\mathrm{w}$ tekstach farmaceutycznych przy pomocy typowych i skonwencjonalizowanych środków językowych.

Dyskurs farmaceutyczny obejmuje teksty mówione (np. komunikacja $\mathrm{z}$ pacjentem $\mathrm{w}$ aptece) i pisane (np. ulotka informacyjna dla pacjentów, reklama leku), tworzone i wykorzystywane w pewnych kontekstach zawodowych do osiągnięcia określonych celów komunikacyjnych, przeznaczone dla innych specjalistów legitymujących się tym samym lub innym poziomem wiedzy fachowej (np. lekarze, farmaceuci, pielęgniarki itp.), adeptów z branży farmaceutycznej (uczniów techników farmaceutycznych, studentów uczelni medycznych, stażystów itp.) lub laików (pacjentów).

Aby jeszcze dokładniej opisać specyfikę dyskursu farmaceutycznego, skorzystam z modelu opisowego zaproponowanego przez Gunnarson (2009: 5-11), który można zastosować do dowolnego typu dyskursu profesjonalnego i który obejmuje sześć czynników, a mianowicie: 1) relacja dyskursu profesjonalnego do innych dyskursów zawodowych i ogólnych, a także dziedzin specjalistycznych; 2) ukierunkowany cel i usytuowanie dyskursu profesjonalnego; 3) konwencjonalna forma dyskursu profesjonalnego; 4) używanie dyskursu profesjonalnego w grupie uporządkowanej społecznie; 5) funkcjonowanie dyskursu profesjonalnego w ramach społeczno-instytucjonalnych; 6) dynamiczny charakter dyskursu profesjonalnego.

Roemer i Schulze (2008: 266) uważają, że istnieje dialektalna relacja między językiem specjalistycznym a dziedziną wiedzy specjalistycznej: język specjalistyczny konstytuuje dziedzinę wiedzy, a specyfika i rozwój danej dziedziny wiedzy kształtuje ten typ języka. Wobec tego język używany przez specjalistów $\mathrm{z}$ danej dziedziny (np. farmacji lub farmakologii) odzwierciedla ich wiedzę 
i umiejętności, a tym samym odróżnia ich od ekspertów z innych dziedzin lub dyscyplin, a także od osób niebędących ekspertami (Gunnarson 2009: 6). Np. język używany w charakterystykach produktów leczniczych lub w szablonowych protokołach badań klinicznych leków różni się znacznie - pod względem terminologii, frazeologii specjalistycznej i stylu - od bardziej przystępnie napisanych ulotek informacyjnych dla pacjentów. W tym przypadku sposób użycia języka podkreśla rozdźwięk między poziomem wiedzy specjalistycznej a umiejętnościami czytelników poszczególnych typów i gatunków tekstów farmaceutycznych.

Dyskurs profesjonalny jest wyraźnie zorientowany na konkretne cele komunikacyjne, ponieważ każda grupa zawodowa (np. lekarze lub farmaceuci), organizacja czy instytucja (np. Europejska Agencja Leków, Ministerstwo Zdrowia, producent leków, dystrybutor leków, szpital, apteka) działają przez pryzmat określonych celów opisanych $\mathrm{w}$ dokumentach wykorzystywanych w tych podmiotach i odnoszących się do konkretnych działań prowadzących do osiągnięcia pożądanych rezultatów (Gunnarson 2009: 6). I tak: producenci leków są prawnie zobowiązani do prowadzenia badań klinicznych swoich produktów w celu uzyskania zezwolenia na ich sprzedaż; farmaceuci są zobowiązani do sprzedaży leków pacjentom, udzielania pacjentom informacji na temat tańszych leków zastępczych (generycznych), o ile takowe są dostępne (np. w Polsce), do udzielania wyjaśnień dotyczących stosowania i podawania leków pacjentom; Komisja Europejska wymaga od producentów produktów leczniczych sporządzenia skróconej charakterystyki produktu i przedstawienia go Europejskiej Agencji Leków lub właściwemu organowi krajowemu w celu uzyskania zezwolenia na sprzedaż w Unii Europejskiej. Treść reklamy leków jest również regulowana odpowiednimi przepisami, m.in. ustawą Prawo Farmaceutyczne ${ }^{6}$ oraz odpowiednimi rozporządzeniami dotyczącymi reklamy leków. Oprócz ustawodawstwa państwowego, praktyki zawodowe mogą być również regulowane przez samych specjalistów zrzeszonych w organizacjach branżowych, sporządzających takie dokumenty, jak regulaminy i kodeksy etyczne, np. kodeks etyki Royal Pharmaceutical Society ${ }^{7}$ (Wielka Brytania) z maja 2001 roku czy Kodeks Etyki Zawodowej Aptekarza $\mathrm{RP}^{8}$ z 2012 roku, uchwalony 22 stycznia na VI Ogólnopolskim Zjeździe Farmaceutów w Szczyrku.

6 Ustawa z dnia 6 września 2001 roku Prawo farmaceutyczne (z późn. zmianami) (Dz.U. 2001 Nr 126, poz. 1381).

7 Zob. https://onlinelibrary.wiley.com/doi/pdf/10.1002/9780470690642.app7 (dostęp: 26.07.2020).

8 Zob. https://www.nia.org.pl/wpcontent/uploads/2018/05/KodeksEtykiAptekarza_oryginal.pdf(dostęp: 26.07.2020). 
Zdaniem Gunnarson (2009: 8) każdy dyskurs profesjonalny stanowi zorganizowany społecznie - poprzez odpowiednie hierarchie władzy - zbiór działań zawodowych, który wpływa na wybór skutecznych metod komunikacji w danej branży, w obrębie grup zawodowych i instytucji oraz między nimi. W związku z tym za rozwój i charakter dyskursu farmaceutycznego, jak w wypadku każdego innego dyskursu profesjonalnego, odpowiedzialni są wszyscy członkowie społeczności tego dyskursu, zarówno profesjonaliści, jak i nieprofesjonaliści ${ }^{9}$. Niektóre zmiany widać na przykładzie języka używanego w ulotkach dla pacjentów w Wielkiej Brytanii. Zamiast bardziej formalnych, specjalistycznych określeń, takich jak indications („wskazania”) lub counterindications („przeciwwskazania”) spotykamy obecnie przejrzyste zdania pytające, np. What is this medicine for? lub Who should not take this medicine? Podobnie w ulotkach znajdujących się $\mathrm{w}$ opakowaniach leków ogólnodostępnych ${ }^{10}$, oprócz terminów specjalistycznych znajdujemy w nawiasach wyjaśnienia w języku ogólnym (np. difficulties sleeping - insomnia, enlarged bowel - megacolon). Producenci leków wyszli więc naprzeciw oczekiwaniom pacjentów, aby ulotki informacyjne były napisane bardziej zrozumiałą i prostszą angielszczyzną. Jest to szczególnie istotne w przypadku leków ogólnodostępnych, ponieważ adresatem ulotki jest przede wszystkim pacjent, a nie tylko specjaliści (lekarze czy farmaceuci).

Wreszcie należy zaznaczyć, że dyskurs farmaceutyczny funkcjonuje w złożonym zestawie ram, m.in. prawno-politycznych, ekonomicznych, technologicznych, społeczno-kulturowych i językowych, które przyczyniają się do jego konwencjonalizacji. Ze względu na ramy prawne i polityczne wiele tekstów farmaceutycznych powstaje w wyniku zobowiązań prawnych, zarówno krajowych, jak i międzynarodowych. Na dyskurs farmaceutyczny wpływają również ramy językowe, np. polityka językowa prowadzona w sposób eksplicytny lub implicytny (tj. przy pomocy lub bez pomocy dodatkowych regulacji) przez rządy, organizacje i instytucje, która ma na celu zagwarantowanie, że dyskurs specjalistyczny (np. słownictwo, terminologia, wzorce gatunkowo-tekstowe) przyczynia się do skutecznego osiągnięcia celów zawodowych, o czym bardziej szczegółowo pisze Gunnarson (2009: 9-10). W Polsce szczegółowe wytyczne językowe odnoszą się do informacyjnych ulotek dla pacjentów, np. Rozporządzenia Ministra Zdrowia w sprawie wymagań dotyczących oznakowania opakowań produktu leczniczego i treści ulotki (Dz.U. Nr 39, poz. 321; Dz.U. 2015 r., poz. 1109) oraz Rozporządzenie Ministra Zdrowia z 16 sierpnia 2018 roku, zmieniające rozporządzenia

9 Przykładem takich działań jest specjalny raport opracowany na zlecenie Komisji Europejskiej, zalecający określone zmiany w języku ulotek dla pacjentów (Van Dijk i in. 2014).

${ }_{10}$ Chodzi o tzw. leki bez recepty (OTC/Over-the-Counter). 
w sprawie wymagań dotyczących oznakowania opakowań produktu leczniczego i treści ulotki. Bardziej ogólne wytyczne możemy znaleźć w art. 63(2) Dyrektywy 2001/83/WE Parlamentu Europejskiego i Rady z 6 listopada 2001 roku w sprawie wspólnotowego kodeksu odnoszącego się do produktów leczniczych stosowanych u ludzi (Dz.U. L 311, 28.11.2001, p. 67).

Podsumowując tę część artykułu, podkreślam, że złożoność dyskursu farmaceutycznego jest ugruntowana w zorientowaniu tego dyskursu na konkretne cele zawodowe, usytuowaniu w środowisku eksperckim, funkcjonowaniu w skonwencjonalizowanej formie, używaniu przez różne grupy społeczne (specjalistów oraz laików), a także w zależności od różnych uwarunkowań prawnych, technologicznych, społecznych, kulturowych, w tym językoznawczych.

\section{Odmiany tekstów w dyskursie farmaceutycznym}

$\mathrm{Na}$ dyskurs farmaceutyczny składają się rozmaite teksty używane w różnorodnych sytuacjach komunikacyjnych wiążących się w jakiś sposób z lekami (produktami leczniczymi), począwszy od opracowywania, testowania, produkcji i dystrybucji, aż po sprzedaż leków docelowym klientom. W odmiennych kontekstach od członków społeczności dyskursu wymagany jest różny poziom profesjonalnej wiedzy specjalistycznej - inny wśród specjalistów z branży farmaceutycznej, inny w wypadku konsumentów leków (pacjentów) - niezbędny do tego, aby zrozumieć informacje przekazywane w różnych typach i gatunkach tekstach farmaceutycznych.

Na dyskurs farmaceutyczny składają się różne typy tekstów (pisane i mówione), które wykazują podobieństwo w odniesieniu do takich cech gatunkowych, jak nadawca tekstu, odbiorca tekstu, struktura, a także funkcja komunikacyjna. Spośród pisanych tekstów farmaceutycznych można wymienić następujące:

- ulotka informacyjna dla pacjentów $w^{11}$;

- charakterystyka produktu leczniczego (ChpL);

- protokół badania klinicznego ${ }^{12}$;

- karta obserwacji klinicznej;

${ }^{11}$ W tym miejscu można wprowadzić rozróżnienie - ze względu na potencjalnych adresatów tekstu i sposób sprzedaży - na ulotki przygotowane dla leków sprzedawanych na receptę oraz dla leków ogólnodostępnych.

12 Dokumentacja badania klinicznego leku obejmuje m.in. broszurę badacza, charakterystykę produktu leczniczego, formularz świadomej zgody, protokół badania klinicznego, kartę obserwacji klinicznej, ubezpieczenie OC, plan analizy statystycznej, raport końcowy. 
- opakowania leków;

- ulotka reklamowa;

- reklamy leku (telewizyjne, na billboardach, internetowe itp.);

- prezentacje leku;

- bazy leków (np. Pharmindex, Baza Leków i Środków Ochrony Zdrowia BLOZ).

Oprócz tekstów pisanych, na dyskurs farmaceutyczny składają się również teksty mówione, do których należą np.:

- rozmowa farmaceuty z pacjentem w aptece;

- codzienne rozmowy zawodowe w aptece ogólnodostępnej lub szpitalnej (pomiędzy personelem aptecznym: kierownikiem apteki, farmaceutą, technikami farmacji, pomocą apteczną);

- prezentacja leku (prelekcja);

- rozmowa handlowa (np. farmaceuty i przedstawiciela farmaceutycznego);

- rozmowy zawodowe w laboratorium farmaceutycznym.

Ponieważ dyskurs farmaceutyczny nie ma charakteru autonomicznego, ale - jak wspomniałem - zazębia się z innymi dyskursami (medycznym, akademickim, prawniczym itp.), to na jego kształt wpływają również inne typy i gatunki tekstów, np. artykuły naukowe $\mathrm{z}$ dziedziny farmacji i farmakologii, rozdziały w monografiach specjalistycznych, monografie specjalistyczne, podręczniki akademickie, encyklopedie leków, teksty prawne i prawnicze traktujące o produktach leczniczych (np. Ustawa z dnia 6 września 2001 roku Prawo farmaceutyczne, z późn. zmianami) i wiele innych. W kolejnej części artykułu przyjrzę się najnowszym badaniom językoznawczym prowadzonym na niektórych z wymienionych tekstów farmaceutycznych.

\section{Badania językoznawcze i interdyscyplinarne nad dyskursem farmaceutycznym}

Zważywszy na interdyscyplinarny i nieautonomiczny charakter dyskursu farmaceutycznego, o którym pisałem wcześniej, często w badaniach językoznawczych, np. zorientowanych na analizę zróżnicowania gramatyki, leksyki, frazeologii i terminologii, teksty farmaceutyczne traktowano jako składowe szeroko rozumianego dyskursu medycznego (Biber, Finegan 1994; Gotti, Meyer-Salager 2006) lub nawet biomedycznego (Verdaguer i in. 2013). Możemy jednak odnaleźć badania poświęcone analizie językowej jednego typu tekstów oraz ograniczonego zestawu cech językowych (np. Gledhill 1995a, 1995b; Paiva 2000). Gledhill przeanalizował 150 artykułów naukowych (0,5 mln wyrazów tekstowych) dotyczących raka i farmakologii, opublikowanych w recenzowanych 
czasopismach naukowych i zebranych w specjalnie opracowanym Korpusie Nauk Farmaceutycznych (Pharmaceutical Science Corpus, PSC). Celem jego badania było „scharakteryzowanie frazeologii powiązanej z wybranymi konstrukcjami gramatycznymi w artykułach naukowych oraz w poszczególnych sekcjach artykułów naukowych, a mianowicie w tytułach, streszczeniach, wstępach, metodach, wynikach i dyskusji” (Gledhill 1995a: 2). Bardziej kompleksową analizę zróżnicowania języka oraz frazeologii w różnych typach i gatunkach tekstów farmaceutycznych przeprowadził z perspektywy frazeologii dystrybucyjnej Grabowski (2015a, 2015b, 2015c), który wykorzystał metodologię językoznawstwa korpusowego do opisu leksyki i frazeologii (słów kluczowych, zbitek leksykalnych i ram frazowych) w specjalnie do tego celu zebranym korpusie angielskich ulotek dla pacjentów, charakterystyk produktów leczniczych, protokołów badań klinicznych oraz podręczników akademickich z dziedziny farmakologii. W innym badaniu zorientowanym bardziej na problemy metodologiczne, Grabowski (2018a) opisał odtwarzalne zbitki leksykalne używane przy opisie interakcji leków. Innym ważnym problemem badawczym jest zróżnicowanie terminologiczne dyskursu farmaceutycznego (Maslova, Korzhavykh 2011; Burdina, Mishlanova/Бурдина, Мишианова 2013; Burdina/Бурдина 2015).

Do jednych z najczęściej analizowanych pod względem językowym typów tekstów farmaceutycznych należy ulotka informacyjna dla pacjentów (patient information leaflet). Badania koncentrujące się na opisie leksyki, frazeologii oraz stylu wykonano przykładowo na ulotkach angielskich (Paiva 2000; Clerehan i in. 2009; Grabowski 2015a), włoskich ${ }^{13}$ (Cacchiani 2006, 2016), polskich (Grabowski 2014) i rosyjskich (Grabowski 2019).

Biorąc pod uwagę teksty mówione, szczególną popularnością (i długą tradycją ${ }^{14}$ ) cieszą się na całym świecie badania nad komunikacją między pacjentem a farmaceutą w aptece (np. Sleath 1996; Banks i in. 2007; Garjani i in. 2009; Shah, Chewning 2006; Chui i in. 2009; Murad i in. 2014; Olsson i in. 2014). Prowadzone są również badania nad rolą różnic kulturowych w komunikacji pacjenta $\mathrm{z}$ farmaceutą, np. w RPA, gdzie podjęto badania nad stopniem zrozumienia informacji uzyskanych od farmaceutów $\mathrm{w}$ odniesieniu do przyjmowania leków antyretrowirusowych (Watermeyer, Penn 2009a, 2009b).

${ }^{13} \mathrm{~W}$ przytoczonych badaniach język i styl włoskich ulotek został porównany z tekstami w języku angielskim. W podobny sposób Grabowski (2018b) porównał odtwarzalne frazeologizmy (zbitki wielowyrazowe) w ulotkach dla pacjentów napisanych w języku polskim i angielskim.

${ }^{14} \mathrm{~Np}$. Ludy i in. (1977) przeanalizowali komunikację pacjenta $\mathrm{z}$ farmaceutą w dwóch różnych scenariuszach (prywatna konsultacja i wizyta w aptece), również uwzględniając pomiar stopnia satysfakcji pacjenta z uzyskanej informacji. 
Wobec powyższego można stwierdzić, że dyskurs farmaceutyczny i badania nad tzw. językiem leków (również interdyscyplinarne), tj. przeprowadzane na tekstach traktujących o lekach i opracowanych dla celów informacyjnych, marketingowych, reklamowych, badawczych, prawnych itp., mają przede sobą ogromne perspektywy - przede wszystkim ze względu na użyteczność wyników takich badań dla społeczeństwa ${ }^{15}$. Jeśli zaś chodzi o badania stricte językoznawcze, to przynajmniej w Polsce ${ }^{16}$ istnieje duża luka w badaniach nad tekstami farmaceutycznymi - z perspektywy analizy dyskursu, stylistyki, leksyki, frazeologii, terminologii i terminografii, analizy konwersacyjnej itp. - których wyniki byłyby interesujące nie tylko dla naukowców badających ten typ dyskursu.

\section{Podsumowanie}

Celem niniejszego artykułu było przybliżenie czytelnikom specyfiki dyskursu farmaceutycznego, a także składających się nań tekstów pisanych i mówionych. Zwróciłem szczególną uwagę na dwie kwestie. Po pierwsze, zarówno w Polsce, jak i na całym świecie dyskurs farmaceutyczny oraz teksty farmaceutyczne często zaliczane są do szerzej rozumianego dyskursu medycznego lub biomedycznego. Po drugie, dyskurs farmaceutyczny nie ma charakteru autonomicznego, ale powiązany jest również z dyskursem medycznym, prawnym czy też akademickim, które przenikają się w tekstach farmaceutycznych. Następnie bardziej szczegółowo scharakteryzowałem dyskurs farmaceutyczny w oparciu o model opisowy zaproponowany przez Bhatię (2004) i Gunnarson (2009). W dalszej części w dużym skrócie przytoczyłem przykłady niektórych badań językoznawczych i interdyscyplinarnych prowadzonych nad wybranymi typami i gatunkami tekstów farmaceutycznych, zarówno pisanych, jak i mówionych.

Przedstawiony przegląd pola badawczego pozwala sądzić, że zarówno w Polsce, jak i na świecie istnieje ogromny potencjał prowadzenia szeroko

15 Warto w tym miejscu nawiązać do pojęcia tzw. farmaceutykalizacji (pharmaceuticalization), o którym piszą np. Williams i in. (2011: 711, cyt. w Johnson i in. 2016: 5), aby określić wielość różnych aspektów życia, które stanowią „okazję” do przyjmowania leków lub produktów leczniczych (pharmaceutical intervention). Johnson i in. (2016: 6) przytaczają również wiele innych przykładów ciekawych badań, m.in. nad wpływem kampanii reklamowych nowych leków na zmianę postrzegania danych schorzeń lub chorób.

16 Więcej o zakresie i stanie badań nad językami specjalistycznymi w Polsce pisze m.in. Grucza (2013). 
zakrojonych badań językoznawczych i interdyscyplinarnych, opisowych oraz eksperymentalnych, nad poszczególnymi odmianami tekstów i rodzajami komunikacji w dyskursie farmaceutycznym, czy w ogóle nad całokształtem komunikacji oraz interakcji społecznych w branży farmaceutycznej. Ważnym krokiem w kierunku upowszechnienia takich badań i podkreślenia ważnej roli skutecznej komunikacji w sektorze opieki zdrowotnej było powołanie w 2015 roku w Bydgoszczy Polskiego Towarzystwa Komunikacji Medycznej (PTKM) ${ }^{17}$. Warto również nadmienić, że w roku 2016 odbyła się I Ogólnopolska Studencka Konferencja Naukowa „Komunikacja w Farmacji” (14 maja w Collegium Medicum UMK w Bydgoszczy) poświęcona m.in. komunikacji farmaceuty z pacjentem oraz opiece farmaceutycznej $\mathrm{w}$ chorobach cywilizacyjnych. Pozostaje mieć nadzieję, że w przyszłości ${ }^{18}$ lączących teorię i praktykę spotkań oraz inicjatyw we wspólpracy uczelni, organizacji pozarządowych, stowarzyszeń i przedsiębiorstw z branży farmaceutycznej będzie coraz więcej, co niewątpliwie przełoży się na większe zainteresowanie badaniami nad dyskursem farmaceutycznym i komunikacją w sektorze opieki zdrowotnej w Polsce.

\section{Bibliografia}

Allum V. (2012), English for Medical Purposes: Doctors, Cambridge.

Banks J., Shaw A., Weiss M. (2007), The community pharmacy and discursive complexity: a qualitative study of interaction between counter assistants and customers, „Health and Social Care in the Community”, t. 15(4), s. 313-321.

Bhatia V. (2004), Worlds of Written Discourse, London-New York.

Biber D., Finegan, E. (1994), Intra-textual variation in medical research articles, [w: ] N. Oostdijk, P. de Haan (red.), Corpus-based Research into Language, Amsterdam, s. 202-221.

Burdina O. (2015), Professional knowledge modelling in pharmaceutical discourse (evidence from term variation), [w:] Proceedings of the conference Mnogomernye miry yazyka. Moscow, s. 196-215 [Бурдина, О.Б. (2015), Моделирование профессионального знания в фармачевтическом дискурсе (на примере вариативности терминологических единии), [в:] Многомерные миры языка. Избранные труды международной научной конфе-

${ }_{17}$ Zob. https://komunikacjamedyczna.pl (dostęp: 26.07.2020).

${ }_{18}$ Zdaniem Gruczy (2013: 25) „sytuacja będzie zapewne zmierzać ku lepszemu, ponieważ w Polsce obserwuje się coraz większe zainteresowanie językami specjalistycznymi i rosnące zapotrzebowanie społeczne na kształcenie thumaczy w zakresie tych języków". 
ренциию, Москва: Российский университет Аружбы народов (РУАН), c. 196-215].

Burdina O., Mishlanova S. (2013), Institutional features of pharmaceutical discourse and their reflection in terminology, „Historical and Social-Educational Thinking”, t. 4(20) s. 190-194 [Бурдина О.Б. \& Мишланова С.А. (2013), Институциональные особенности фармачевтического дискурса и их оттажение в терминологии, Историческая и социально-образовательная мысль, № 4(20), с. 190-194].

Cacchiani S. (2006), Dis/similiarities between patient information leaflets in Britain and Italy: implications for the translator, „New Voices in Translation Studies", nr 2, s. 28-43.

Cacchiani S. (2016), On intralinguistic translation from summaries of product characteristics to patient information leaflets, [w: ] G. Elena Garzone, D. Heaney, G. Riboni (red.), LSP Research and Translation across Languages and Cultures, Newcastle upon Tyne, s. 219-251.

Carra D., Hein M. (2007), Język angielski w aptece, Wrocław.

Chui M., Halton K., Peng J. (2009), Exploring patient-pharmacist interaction differences between the drive-through and walk-in windows, "Journal of the American Pharmacists Association”, t. 49(3), s. 427-431.

Ciecierska J., Jenicke B., Tudruj K. (1983), English for pharmacy: język angielski: podręcznik dla studentów farmacji, Warszawa.

Clerehan R., Hirsh D., Buchbinder R. (2009), Medication information leaflets for patients: the further validation of an analytic linguistic framework, „Communication \& Medicine", t. 6(2), s. 117-128.

Dawidziuk M. (2014), Dyskurs i gatunek wypowiedzi jako podstawowe pojęcia wspótczesnej lingwistyki - wprowadzenie, „Językoznawstwo: współczesne badania, problemy i analizy językoznawcze", nr 8, s. 19-29.

Dobronravov A., Bryzgalin E., Aliochin A. (2017), Farmacevticheskiy diskurs kak sistema mezhdisciplinarnoy kommunikacii, „Kommunikologija”, nr 5(5), s. 59-72 [Аобронравов А.В., Брызгалина Е.В. \& Алёхин А.В. (2017), Фармачевтический, дискурс как система междисиипинарной коммуникации, Коммуникология, № 5(5), с. 59-72].

Donesch-Jeżo E. (2007), English for Students of Pharmacy and Pharmacists, Kraków. Dycha M. (2016), English for Pharmacists. Podręcznik, Warszawa.

Garjani A., Rahbar M., Ghafourian T., Maleki N., Garjani A., Salimnejad M., Shamsmohammadi M., Baghchevan V., Aghajani H. (2009), Relationship of pharmacist interaction with patient knowledge of dispensed drugs and patient satisfaction, „East Mediterranean Health Journal”, t. 15(4), s. 934-943.

Glendinning E., Holmstroem B. (2005), English in Medicine: A Course in Communication Skills, Cambridge. 
Gotti M., Meyer-Salager F. (red.) (2006), Advances in Medical Discourse Analysis: Oral and Written Contexts, Frankfurt.

Grabowski Ł. (2014), On lexical bundles in Polish patient information leaflets: a corpus-driven study, „Studies in Polish Linguistics”, t. 19(1), s. 21-43.

Grabowski Ł. (2015a), Keywords and lexical bundles within English pharmaceutical discourse: a corpus-driven description, „English for Specific Purposes”, nr 38, s. 23-33.

Grabowski Ł. (2015b), Phraseology in English Pharmaceutical Discourse: A Corpus-Driven Study of Register Variation, Opole.

Grabowski Ł. (2015c), Phrase frames in English pharmaceutical discourse: a corpus-driven study of intra-disciplinary register variation, „Research in Language", t. 13(3), s. 266-291.

Grabowski Ł. (2018a), Fine-tuning lexical bundles: A methodological reflection in the context of describing drug-drug interactions, [w: ] J. Kopaczyk, J. Tyrkkö (red.), Applications of Pattern-driven Methods in Corpus Linguistics, Amsterdam, s. 57-80.

Grabowski Ł. (2018b), On identification of bilingual lexical bundles for translation purposes. The case of an English-Polish comparable corpus of patient information leaflets, [w:] R. Mitkov, J. Monti, G. Corpas Pastor, V. Seretan (red.), Multiword Units in Machine Translation and Translation Technology, Amsterdam, s. 182-199.

Grabowski Ł. (2019), Distinctive lexical patterns in Russian patient information leaflets: a corpus-driven study, „Russian Journal of Linguistics”, t. 23(3), s. 659-680.

Grucza S. (2013). Od lingwistyki tekstu do lingwistyki tekstu specjalistycznego. Wydanie trzecie, Warszawa, https://portal.uw.edu.pl/documents/7732735/0/ $\mathrm{SN}+2 .+$ Sambor+Grucza+-+Od+lingwistyki+tekstu+do+lingwistyki+tekst u+specjalistycznego.pdf (dostęp: 10.11.2019).

Gunnarson B. (2009), Professional Discourse, London.

Hull M. (2010), Medical English Clear and Simple. A Practice-based Approach to English for ESL Healthcare Professionals, Philadelphia.

Johnson E., Sjoergen E., Asberg C. (2016), Glocal Pharma: International Brands and the Imagination of Local Masculinity, London.

Kabus J. (2011), Interdyscyplinarność dyskursu, „Językoznawstwo: współczesne badania, problemy i analizy językoznawcze", nr 5, s. 49-55.

Kierczak A. (2009), English for Pharmacists, Warszawa.

Kositskaya F. (2016), Frantsuskiy farmacevticheskiy diskurs $i$ ego zhanrovaya palitra, „TSPU Bulletin”, nr 10(175), s. 71-75 [Косицкая Ф.А. (2016), Франиузский фармацевтический дискурс и его жанровая палитра, Вестник 
ТГПУ, № 10(175), c. 71-75], https://vestnik.tspu.edu.ru/files/vestnik/PDF/ articles/kositskaya_f._1. 71 75_10_175_2016.pdf (dostęp: 4.11.2019). Lipińska A., Wiśniewska-Leśków S. (2018), Język angielski w aptece. Skills upgrade, Wrocław.

Ludy J., Gagnon J., Caiola S. (1977), The patient-pharmacist interaction in two ambulatory settings - it's relationship to patient satisfaction and drug misuse, „Drug Intelligence \& Clinical Pharmacy”, t. 11(2), s. 81-89.

Ławnicka-Borońska M. (2013), Jezzyk polski w medycynie. A Guide to Polish in Medical Practice, Kraków.

Ławnicka-Borońska M., Kubacka K. (2016), Język polski medyczny w wybranych materiałach dydaktycznych ostatniego ćwierćwiecza, „Acta Universitatis Lodziensis. Kształcenie Polonistyczne Cudzoziemców”, nr 23, s. 215-235. Maslova I., Korzhavykh E. (2011), Terminological studies of pharmaceutical discourse: linguodidactic overview, „Polylinguality and Transcultural Practices", nr 1, s. 24-30, http://journa.rudn.ru/polylinguality/article/ view/1778/1251 (dostęp: 19.04.2020).

Mądry M. (2019), Nowe prawo wyrobów medycznych, [w:] Life Sciences Law Blog, https://blog.dzp.pl/pharma/nowe-prawo-wyrobow-medycznych/ (dostęp: 28.10.2019).

Murad M., Chatterley T., Guirguis L. (2014), A meta-narrative review of recorded patient-pharmacist interactions: Exploring biomedical or patient-centered communication?, „Research in Social and Administrative Pharmacy”, t. 10(1), s. $1-20$.

Olsson E., Ingman P., Ahmed B., Kälvemark Sporrong S. (2014), Pharmacistpatient communication in Swedish community pharmacies, "Research in Social and Administrative Pharmacy", t. 10(1), s. 149-155.

Paiva D. (2000), Investigating style in a corpus of pharmaceutical leaflets: results of a factor analysis, [w: ] Proceedings of the Student Workshop of the 38th Annual Meeting of the ACL, Hongkong, 1-8.10.2000, s. 52-59, http://www.itri. brighton.ac.uk/ Daniel.Paiva/acl2000student.finalversion.pdf (dostęp: 3.11.2019).

Piekot T. (2014), Trzy sposoby rozumienia stowa dyskurs, [w:] I. Ukhvanova-Shmigova, M. Sarnowski, T. Piekot, M. Poprawa, G. Zarzeczny (red.), Dyskurs $w$ perspektywie akademickiej, Olsztyn, s. 16-17.

Shah B., Chewning B. (2006), Conceptualizing and measuring pharmacist-patient communication: a review of published studies, „Research in Social and Administrative Pharmacy", t. 2(2), s. 153-185.

Sleath B. (1996), Pharmacist-patient relationships: authoritarian, participatory, or default?, „Patient Education and Counselling”, t. 28(3), s. 253-263. 
Wetermayer J., Penn C. (2009a), Communicating dosage instructions across cultural and linguistic barriers: pharmacist-patient interactions in a South African antiretroviral clinic, „Stellenbosch Papers in Linguistics PLUS”, nr 39, s. $107-125$.

Watermeyer J., Penn C. (2009b), Tell me so I know you understand: pharmacists' verification of patients' comprehension of antiretroviral dosage instructions in a cross-cultural context, „Patient Education and Counselling”, nr 75(2), s. 205-213.

Williams S., Martin P., Gabe J. (2011), The pharmaceuticalisation of society? A framework for analysis, „Sociology of Health and Illness", t. 33(5), s. 10-25, https://onlinelibrary.wiley.com/doi/epdf/10.1111/ j.1467-9566.2011.01320.x (dostęp: 28.11.2019).

Van Dijk T. (2001), Badania dyskursu, [w:] T. Van Dijk (red.), Dyskurs jako struktura i proces, Warszawa, s. 9-44.

Van Dijk L., Patricio-Monteiro S., Vervole M., de Bie J., Raynor Th. (2014), Study on the Package Leaflets and the Summaries of Product Characteristics of Medicinal Products for Human use. PIL-S study, https://ec.europa.eu/ health/sites/health/files/files/committee/75meeting/pil_s.pdf (dostęp: 11.11.2019).

Verdaguer I., Laso N., Salazar D. (red.) (2013), Biomedical English: A Corpus-Based Approach, Amsterdam.

Łukasz Grabowski

\title{
PHARMACEUTICAL TEXTS AND PHARMACEUTICAL DISCOURSE: DEFINITIONS, SPECIFICITY AND AN OVERVIEW OF RESEARCH FIELD
}

\author{
(Summary)
}

This chapter aims to familiarize readers with the specificity of pharmaceutical discourse, including its spoken and written text varieties. I paid particular attention to two issues. Firstly, pharmaceutical discourse and pharmaceutical texts are often classified by researchers into broader category of medical or biomedical discourse. Second, pharmaceutical discourse is not autonomous as it is also permeated with medical, legal, academic and other discourses. Next, pharmaceutical discourse was described in greater detail using descriptive models proposed by Bhatia (2004) and Gunnarson (2009). Finally, a selection of research studies, including linguistic and interdisciplinary ones, conducted on certain pharmaceutical text types and genres, both spoken and written, were presented to provide a more comprehensive overview of the research field.

Key words: pharmaceutical texts, pharmaceutical discourse, professional discourse, text varieties 